\title{
Threat of compulsory licences could increase access to essential medicines
}

\author{
(đ) $(1) \Theta$ OPEN ACCESS \\ Gorik Ooms and Johanna Hanefeld argue that low and middle income countries could increase \\ access to medicines by forming an alliance to credibly threaten companies with compulsory licences
}

\section{Gorik Ooms professor of global health law and governance, Johanna Hanefeld associate professor of health policy and systems}

Department of Global Health and Development, Faculty of Public Health and Policy, London School of Hygiene and Tropical Medicine, London, UK

Access to affordable medicines and vaccines is essential for both universal health coverage and meeting the sustainable development goals. However, as innovations of medicines are owned by companies, it is important to recognise that improving access to them is intertwined with international trade laws and intellectual property rights.

The sustainable goal development targets explicitly recognise this. They include a target for increasing access to medicines using the flexibilities to protect public health in the major international trade agreement that underpins intellectual property rights-namely, the Agreement on Trade Related Aspects of Intellectual Property Rights (TRIPS). ${ }^{1}$ However, many scholars argue that the TRIPS agreement and the subsequent political declaration designed to support countries' access to medicines-the Doha declaration-does not provide a solution for the poorest countries. ${ }^{2}$

The main argument for intellectual property rights is the cost of research and development. Some argue that for medicines this should simply be financed differently-for example, through prize funds financed by public resources. We agree, and in September 2016, the United Nations high level panel on access to medicines issued a report on promoting innovation and access to health technologies. It recommended breaking the connection between the cost of research and development and the end product. $^{3}$

The TRIPS agreement and the Doha declaration "solution" for increasing availability of essential medicines has two distinct advantages over alternative mechanisms: it is already included in international law, and it has the political backing of the sustainable development goal declaration.

In this paper, we discuss the difficulties that low and middle income countries face when they want to use the Doha declaration. However, we also argue that compulsory licences, one of the flexibilities enabled by the Doha declaration, can be used to increase access to essential medicines when used as a threat.

\section{TRIPS agreement}

Intellectual property enables people and companies to benefit economically from their invention. Only the owner of the intellectual property rights can sell, or authorise someone else to sell, a product. However, this monopoly enables the owner to charge an unreasonably high price if they wish. As a counterbalance, governments usually do not grant intellectual property rights easily, and they limit the time for which they apply.

The TRIPS agreement was introduced in 1995 and sets out the minimum standards for intellectual property regulation in World Trade Organization (WTO) member countries. ${ }^{4}$ Before introduction of the agreement, countries could offer intellectual property rights as they saw fit. Some countries offered none at all, and many countries excluded medicines. ${ }^{5}$ In these countries, companies were allowed to produce generic equivalents (copies) of medicines that were protected by patents in other countries.

The TRIPS agreement obliged all WTO member states to provide a minimum level of intellectual property rights. However, it did not create a worldwide system. Instead, it set out international norms for national intellectual property protection systems. Each WTO member state is supposed to create its own system but may work with others to create regional systems.

A patent on a medicine granted by one country's patent office gives the company the right to prevent the production, sale, and importation of generic equivalents in that country. However, it does not affect the production and distribution of generic 
equivalents of the same medicine in other countries. Nevertheless, since the introduction of the TRIPS agreement, a company can expect to find similar intellectual property protection rules in all WTO countries.

The original TRIPS agreement includes several so called "flexibilities." This is the term used for the leeway allowed by the agreement for governments to design their own national intellectual property system. One of the most important tools for increasing access to medicines is the compulsory licence.

A compulsory licence can be issued by a government to a manufacturer of generic products, allowing them to produce copies without consent of the patent owner. The original TRIPS agreement imposed conditions on the use of compulsory licences, to avoid undermining the whole system. The precise scope allowed by these conditions has been the subject of many debates. For access to medicines the most important condition was that the production of copies should predominantly be for use in the country whose government issued the licence.

The original TRIPS agreement did not create a worldwide system but a patchwork of (mostly) national intellectual property systems. Therefore, a compulsory licence issued by the Rwandan government has no validity in Canada, for example. As we will explain below, these countries have not been randomly chosen. A generic manufacturer based in Canada could not produce the equivalent generic medicine for Rwanda. The Canadian government could issue a compulsory licence, but it would be for domestic use in Canada only. In truth, the Rwandan government could issue a compulsory licence allowing only manufacturers in Rwanda to produce generic equivalents. However, if no manufacturers with such capacity exist in Rwanda, the compulsory licence flexibility would be an empty shell.

\section{Effect on prices of antiretroviral medicines}

The TRIPS agreement was made around the time that the first antiretroviral medicines were developed to treat HIV infection. In countries that were wealthy enough to subsidise the treatment cost of at least $\$ 10000(£ 7700, € 8900)$ a year for each patient, these medicines gradually turned HIV infection into a non-fatal chronic condition. Antiretrovirals were the first medicines to demonstrate the effect of the TRIPS agreement. Some low and middle income countries negotiated price reductions with pharmaceutical companies, but these were insufficient to enable combination treatment for everyone in need. At least three countries-Brazil, South Africa, and Thailand-considered using the TRIPS flexibilities to broaden access to antiretroviral medicines. ${ }^{6}$

In 1995, when the TRIPS agreement came into effect, Brazil and Thailand had already begun producing generic equivalents of the first generation of antiretroviral medicines, which were not protected by patent at that time. The TRIPS agreement allowed low and middle income countries to wait until 2005 before implementing the agreement. However, under international pressure, both Brazil and Thailand offered patent protection earlier, and drug companies acquired patents on newer antiretroviral medicines. ${ }^{7}$ Both countries considered using compulsory licences. However, under pressure from industrialised countries Thailand initially backed down, while Brazil faced a request for WTO arbitration from the US. ${ }^{8}$

South Africa had already adopted comprehensive intellectual property law under the apartheid regime. Thus the first and subsequent antiretroviral medicines were protected by patent in South Africa in the 1990s. ${ }^{9}$ In 1997, the post-apartheid government had adopted the Medicines and Related Substances
Control Amendment Act. This allowed it to use another important TRIPS agreement flexibility that enables countries to import medicines without the permission of the patent owner-namely, parallel import. ${ }^{10}$ A lawsuit against the South African government was brought by the South African Pharmaceutical Manufacturers Association and 40 drug companies. This resulted in substantial media attention and triggered an international advocacy campaign for "access to medicines." By April 2001, the drug companies had dropped their lawsuit against the South African government, and in June 2001 the US withdrew its complaint against Brazil.

\section{The Doha declaration}

Widespread criticism of the TRIPS agreement and its consequences for treatment of AIDS led the WTO to adopt a ministerial declaration on public health in Doha, Qatar, in November 2001. The Doha declaration confirmed that compulsory licences and parallel imports, as envisaged by the governments of Brazil, Thailand, and South Africa, did not violate the TRIPS agreement. The declaration also attempted to deal with a problem highlighted by the international advocacy campaign for access to medicines-namely, the challenge faced by countries lacking domestic pharmaceutical manufacturing capacity.

The Doha declaration recognised that "WTO members with insufficient or no manufacturing capacities in the pharmaceutical sector could face difficulties in making effective use of compulsory licensing." It gave a mandate to the TRIPS council to expand the flexibilities, ${ }^{11}$ allowing compulsory licences for export. This was initially temporary, ${ }^{11}$ but recently became a permanent addition to the original TRIPS agreement. ${ }^{13}$ Here, we refer to both as the "Doha declaration solution".

As far as we know, the Doha declaration solution has been used only once. In July 2007, Rwanda notified the WTO that it intended to import a fixed dose combination antiretroviral drug manufactured by the Canadian generic pharmaceutical manufacturer Apotex. In September 2007, Apotex was granted a compulsory licence from the Canadian authorities. ${ }^{14}$ Between 2008 and 2010 Apotex exported three batches of the antiretroviral medicine from Canada to Rwanda using this scheme. ${ }^{15}$ It was a lengthy and cumbersome process, and several commentaries have questioned the efficiency and sustainability of the scheme. ${ }^{16-20}$

Should we consider the Doha declaration solution to be a failure? Is it a smokescreen, designed to give the impression that the WTO cares about access to medicines, while trying to save the TRIPS regime from a real overhaul? With only a single application, it does not have much to show for 15 years of existence. It certainly did not end controversy about high prices and access to medicines. As mentioned above, the September 2016 UN report on promoting innovation and access to health technologies recommended "delinking the cost of research and

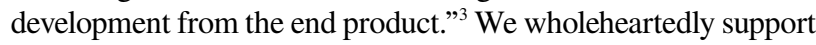
a fundamental rethinking of the concept of intellectual property, but this is not likely to happen without consent of the world's most powerful states. Meanwhile, there may be reasons for not dismissing the Doha declaration solution too hastily.

\section{Hidden power of compulsory licences}

The power of compulsory licences is most obvious when governments use them effectively. However, compulsory licences also have power when governments warn patent owners that they will use them if necessary. For example, when the US 
faced the threat of terrorists using anthrax in October 2001, the US secretary of health and social services wanted to stockpile ciprofloxacin, which was the best available treatment for anthrax. Bayer, the patent owner, demanded the usual price for ciprofloxacin, but when the US and Canada declared they might issue a compulsory licence, Bayer reduced the price. ${ }^{22}$ Neither Canada nor the US needed the Doha declaration to threaten Bayer as there was sufficient manufacturing capacity in both countries (and the Doha declaration came a month later). Thus threatening to use a compulsory licence may be as effective as formally issuing one.

The Doha declaration solution is cumbersome to apply effectively, but it does give countries- even those without domestic manufacturing capacity - the power to threaten to use a compulsory licence. This may have an influence on prices. For example, sofosbuvir is a relatively new and highly effective treatment for hepatitis $\mathrm{C}$, but its high price in some countries has proved controversial. Sofosbuvir came to the market in 2007. According to Iyengar and colleagues, the price of sofosbuvir was \$64 680 per treatment in the US and \$539 in India in $2015 .^{23}$ In 2015 , no country had issued a compulsory licence for sofosbuvir. The first such licence was issued by the Malaysian government in September 2017. ${ }^{24}$

Why the disparity in the price of sofosbuvir in the US compared with India? The prices were set by the originator, or by generic manufacturers working with a voluntary licence given by the patent owner. Thus, the "discount" for India, given or allowed by the patent owner, was $99 \%$ before any compulsory licence was issued. This is similar to the price reduction of the classic combination antiretroviral therapy, attributed to generic competition. ${ }^{25}$ We cannot be certain that the risk of a compulsory licence was the main reason for the patent owner of sofosbuvir allowing a $99 \%$ discount, but there is no other obvious explanation.

India has manufacturers that can produce generic equivalents of sofosbuvir, as does Malaysia. Can countries without manufacturing capacity use the same strategy? Before the Doha declaration, patent owners would not have been impressed by a threat to issue a compulsory licence from a country without domestic manufacturing capacity. Since the declaration, such a threat would be credible. Although the Doha Declaration solution has been used only once, this was enough to show that it can be done, as long as countries with manufacturing capacity are willing to cooperate.

Low and middle income countries would be in a stronger position if they declared their commitment to cooperate to make the Doha Declaration solution work. One option might be for them to agree on specific conditions under which they would issue compulsory licences for export based on the Doha declaration, if required by another member of the alliance. ${ }^{26}$ This would increase the credibility of threats to issue a compulsory licence by countries without manufacturing capacity. It would also give a signal to generic manufacturers of the potential size of the market, if all countries participating in this alliance would buy from the cheapest provider within the alliance.

We should not be naive. As Sell points out, "there is a dizzying array of extra intellectual property protection that is being imposed on developing countries, such as TRIPS Plus agreements, in the form of bilateral agreements, free trade agreements, and plurilateral negotiations such as anti-counterfeiting trade agreements." ${ }^{27}$ The political pressure used by rich countries against poorer countries to dissuade them from using their rights under the TRIPS agreement and the Doha declaration has increased. However, the governments of low and middle income countries with manufacturing capacity are not as powerless as before the Doha declaration. They can issue compulsory licences for all medicines needed to protect public health without violating the TRIPS agreement. They can declare their intention to help low and middle income countries without manufacturing capacity and, by doing so, empower these other countries. Whether they have the will to confront the likely political pressure is a different matter.

\section{Key messages}

Threatening to use a compulsory licence may be as effective as formally issuing a compulsory licence

Although the Doha declaration solution is cumbersome to apply, it gives all countries the power to threaten with compulsory licences

Low and middle income countries would be in a stronger position if they declared their commitment to cooperate to make the Doha declaration solution work

Contributors and sources: $\mathrm{GO}$ and $\mathrm{JH}$ conceptualised and wrote this article together. Competing interests: We have read and understood BMJ policy on declaration of interests and have no relevant interests to declare.

Provenance and peer review: Not commissioned; externally peer reviewed.

United Nations. Transforming our world: the 2030 agenda for sustainable development. https://sustainabledevelopment.un.org/post2015/transformingourworld

2 Abbas MZ, Riaz S. Compulsory licensing and access to medicines: TRIPS amendment allows export to least-developed countries. Journal of Intellectual Property Law \& Practice 2017;12:451-210.1093/jplp/jpx065.

3 UN secretary-general's high-level panel on access to medicines. Promoting innovation and access to health technologies. United Nations, 2015. http://www.unsgaccessmeds. org/final-report

4 Gervais D. The TRIPS Agreement: drafting history and analysis. 4th ed. Sweet \& Maxwell, 2012.

5 Drahos P. Developing countries and international intellectual property standard-setting. $J$ World Intellect Prop 2002;5:765-8910.1111/j.1747-1796.2002.tb00181.x. https://www. anu.edu.au/fellows/pdrahos/articles/pdfs/2002devcountriesandipstandards.pdf

6 Hestermeyer H. Human rights and the WTO: the case of patents and access to medicines. Oxford University Press, 2007.

7 Ford N, Wilson D, Costa Chaves G, Lotrowska M, Kijtiwatchakul K. Sustaining access to antiretroviral therapy in the less-developed world: lessons from Brazil and Thailand. AIDS 2007;21(Suppl 4):S21-9. 10.1097/01.aids.0000279703.78685.a6 17620749

8 Galvão J. Brazil and access to HIV/AIDS drugs: a question of human rights and public health. Am J Public Health 2005:95:1110-6. 10.2105/AJPH.2004.044313 15933238

9 Attaran A, Gillespie-White L. Do patents for antiretroviral drugs constrain access to AIDS treatment in Africa? JAMA 2001;286:1886-92. 10.1001/jama.286.15.1886 11597292

10 't Hoen E. TRIPS, pharmaceutical patents, and access to essential medicines: a long way from Seattle to Doha. Chic J Int Law 2002;3:27-46.15709298

11 Matthews D. WTO decision on implementation of paragraph 6 of the DOHA Declaration on the TRIPs Agreement and public health: a solution to the access to essential medicines problem?J Int Econ Law 2004;7:73-10710.1093/jiel/7.1.73https://qmro.qmul.ac.uk/xmlui/ bitstream/handle/123456789/983/MatthewsTheWTODecision2004POSTP.pdf

13 Abbott FM, Reichman JH. The Doha Round's public health legacy: strategies for the production and diffusion of patented medicines under the amended TRIPS provisions. $J$ Int Econ Law 2007;10:921-8710.1093/jiel/jgm040https://scholarship.law.duke.edu/cgi/ viewcontent.cgi?article $=2490 \&$ context=faculty_scholarship

14 Rimmer M. Race against time: the export of essential medicines to Rwanda. Public Health Ethics 2008;1:89-10310.1093/phe/phn011. https://papers.ssrn.com/sol3/papers.cfm? abstract_id $=1260188$

15 Sekalala S. Soft law and global health problems: lessons from responses to HIV/AIDS malaria and tuberculosis. Cambridge University Press, 201710.1017/9781107278950.

16 Cohen-Kohler JC, Esmail LC, Cosio AP. Canada's implementation of the paragraph 6 decision: is it sustainable public policy? Global Health 2007;3:12. 10.1186/1744-8603-3-12 18062821

17 Greenbaum JL. Trips and public health: solutions for ensuring global access to essential AIDS medication in the wake of the paragraph 6 waiver. $J$ Contemp Health Law Policy 2008;25:142-65.19137750

18 Goodwin PE. Right idea, wrong result-Canada's access to medicines regime. Am J Law Med 2008:34:567-84. 10.1177/009885880803400404 19216248

19 Elliott R. Delivering on the pledge: global access to medicine, WTO rules, and reforming Canada's law on compulsory licensing for export. McGill Int J Sust Dev Law Policy 2007;3:23-67. http://www.aidslaw.ca/site/wp-content/uploads/2013/04/Elliott_JSDLP3-1. pdf

20 Reichman JH. Comment: compulsory licensing of patented pharmaceutical inventions: evaluating the options. J Law Med Ethics 2009;37:247-63. 10.1111/j.1748-720X.2009.00369. 19493070

22 Mullin TF. AIDS, anthrax, and compulsory licensing: has the United States learned anything-a comment on recent decisions on the international intellectual property rights of pharmaceutical patents. ILSA J Int Comp Law 2002;9:185. https://nsuworks.nova.edu/ cgi/viewcontent.cgi?article $=1414$ \&context=ilsajournal

23 lyengar S, Tay-Teo K, Vogler S, etal . Prices, costs, and affordability of new medicines for hepatitis C in 30 countries: an economic analysis. PLoS Med 2016;13:e1002032. 10.1371/journal.pmed.1002032 27243629 
24 Saez C. Malaysia grants compulsory licence for generic sofosbuvir despite Gilead licence. Intellectual Property Watch, 2017. https://www.ip-watch.org/2017/09/15/malaysia-grantscompulsory-licence-generic-sofosbuvir-despite-gilead-licence/

25 Médecins Sans Frontières. Untangling the web of price reductions: a pricing guide for the purchase of ARVs for developing countries. 2006. http://d2pd3b5abq75bb.cloudfront.net/ 2013/09/30/12/40/12/843/AIDS_report_UTW9_ENG_2006.pdf

26 Ooms G, Forman L, Williams OD, Hill PS. Could international compulsory licensing reconcile tiered pricing of pharmaceuticals with the right to health?BMC Int Health Hum Rights 2014;14:37. 10.1186/s12914-014-0037-4 25518744
27 Sell SK. TRIPS was never enough: vertical forum shifting, FTAs, ACTA, and TPP. J Intell Prop Law 2010;18:447-78. https://digitalcommons.law.uga.edu/cgi/viewcontent.cgi? referer=https://www.google.co.uk/\&httpsredir=1\&article=1186\&context=jipl

Published by the BMJ Publishing Group Limited. For permission to use (where not already granted under a licence) please go to http://group.bmj.com/group/rights-licensing/ permissions This is an Open Access article distributed in accordance with the Creative Commons Attribution Non Commercial (CC BY-NC 4.0) license, which permits others to distribute, remix, adapt, build upon this work non-commercially, and license their derivative works on different terms, provided the original work is properly cited and the use is non-commercial. See: http://creativecommons.org/licenses/by-nc/4.0/. 